\title{
Regulatory B and T lymphocytes in multiple sclerosis: friends or foes?
}

\author{
Georgios K. Vasileiadis ${ }^{1}$ - Efthymios Dardiotis ${ }^{1} \cdot$ Athanasios Mavropoulos $^{2} \cdot$ Zisis Tsouris $^{1} \cdot$ Vana Tsimourtou $^{1}$. \\ Dimitrios P. Bogdanos ${ }^{2} \cdot$ Lazaros I. Sakkas $^{2} \cdot$ Georgios M. Hadjigeorgiou ${ }^{1,3}$
}

Received: 4 July 2018 / Accepted: 17 October 2018 / Published online: 10 November 2018

(c) The Author(s) 2018

\begin{abstract}
Current clinical experience with immunomodulatory agents and monoclonal antibodies in principle has established the benefit of depleting lymphocytic populations in relapsing-remitting multiple sclerosis (RRMS). B and T cells may exert multiple pro-inflammatory actions, but also possess regulatory functions making their role in RRMS pathogenesis much more complex. There is no clear correlation of Tregs and Bregs with clinical features of the disease. Herein, we discuss the emerging data on regulatory T and B cell subset distributions in MS and their roles in the pathophysiology of MS and its murine model, experimental autoimmune encephalomyelitis (EAE). In addition, we summarize the immunomodulatory properties of certain MS therapeutic agents through their effect on such regulatory cell subsets and their relevance to clinical outcomes.
\end{abstract}

Keywords Autoimmunity $\cdot$ Demyelination $\cdot$ Immunity $\cdot$ Regulation

$\begin{array}{ll}\text { Abbreviations } \\ \text { Aqp } & \text { Aquaporin } \\ \text { APC } & \text { Antigen-presenting cell } \\ \text { BBB } & \text { Blood-brain barrier } \\ \text { CSF } & \text { Cerebrospinal fluid } \\ \text { EDSS } & \text { Expanded disability status scale } \\ \text { ELISpot } & \text { Enzyme-linked immunospot } \\ \text { FACS } & \text { Fluorescence-activated cell sorting } \\ \text { FoxP3 } & \text { Forkhead box P3 } \\ \text { IFN } & \text { Interferon } \\ \text { mAb } & \text { Monoclonal antibodies }\end{array}$

Georgios K. Vasileiadis and Efthymios Dardiotis share the first authorship.

Dimitrios P. Bogdanos and Lazaros I. Sakkas share the last authorship.

Efthymios Dardiotis

edar@med.uth.gr

1 Department of Neurology and Laboratory of Neurogenetics, Faculty of Medicine, School of Health Sciences, University General Hospital of Larissa, University of Thessaly, Biopolis, 40500 Larissa, Greece

2 Department of Rheumatology and Clinical Immunology, Faculty of Medicine, School of Health Sciences, University General Hospital of Larissa, University of Thessaly, Biopolis, 40500 Larissa, Greece

3 Department of Neurology, Medical School, University of Cyprus, 1678 Nicosia, Cyprus

$\begin{array}{ll}\text { MBP } & \text { Myelin basic protein } \\ \text { MS } & \text { Multiple sclerosis } \\ \text { NMO } & \text { Neuromyelitis optica } \\ \text { PB } & \text { Peripheral blood } \\ \text { PBMC } & \text { Peripheral blood mononuclear cells } \\ \text { PPD } & \text { Purified protein derivative of tuberculin } \\ \text { RORC } & \text { Retinoid-related orphan receptor g } \\ \text { RRMS } & \text { Relapsing-remitting MS } \\ \text { SPMS } & \text { Secondary progressive MS } \\ \text { Tbet } & \text { T-box expressed in T cells } \\ \text { TGF } & \text { Transforming growth factor } \\ \text { Th } & \text { T-helper } \\ \text { TNF } & \text { Tumor necrosis factor } \\ \text { Treg } & \text { T-regulatory cells } \\ \text { VLA } & \text { Very late antigen }\end{array}$

\section{Introduction}

Multiple sclerosis

\section{Overview}

Multiple sclerosis (MS) is an inflammatory disorder of the brain and spinal cord characterized by focal lymphocytic infiltration and microglial activation leading to neurodegeneration and progressive disability [1]. 
MS is the most common chronic neurological disease in young and middle-aged adults, affecting 2.5 million people worldwide. It is more prevalent in Northern Europe, Canada and Oceania and shows a female preponderance, with a female-to-male 2:1 ratio. MS is classified into three subtypes, namely relapsing-remitting MS (RRMS), primary progressive MS (PPMS) and secondary progressive MS (SPMS). RRMS, which accounts for $80 \%$ of the patients, presents at first with an acute episode affecting one or more sites, known as the clinically isolated syndrome (CIS). A second attack of demyelination occurring afterward is required to meet the diagnostic criteria for RRMS. Ultimately, around $65 \%$ of RRMS patients enter the SPMS phase, while in $20 \%$ the illness is progressive from onset, hence the characterization as PPMS [1].

The first therapeutic regimens that became available for MS were interferon- $\beta$ and glatiramer acetate [2-4]. The FDA has currently licensed several immune disease-modifying therapies (DMTs), most of which have been validated in other autoimmune diseases as well. These include monoclonal antibodies, such as rituximab (anti-CD20) [5] and alemtuzumab (anti-CD52) [6,7], and oral agents with immunomodulatory properties, such as fingolimod, dimethyl fumarate and teriflunomide [8-10]. Clinical trials testing anti-CD20-mediated depletion of peripheral B cells showed promising effects against the development of new central nervous system (CNS) lesions and relapses [11, 12]. Despite some efficacy of therapies, there are still unmet therapeutic needs in MS. Besides, current therapeutic agents are costly summing up to a total annual cost of approximately 15 billion euros for MS in Europe in 2010.

\section{Pathogenesis}

Environmental, genetic, epigenetic and immunological factors are implicated in the development of MS [13, 14]. Myelin-targeting autoreactive $\mathrm{CD} 4(+) \mathrm{T}$ cells that pass through a disrupted blood-brain barrier (BBB) and enter the CNS were initially considered the critical orchestrators in the pathogenesis of MS [15]. Activated by microglia, astrocytes or other immune cells through HLA class II presentation of myelin antigens, CD4(+) T cells express different cytokines depending on their subset. Th1 and Th17 cells express proinflammatory cytokines, such as IFN- $\gamma$ and IL-17, respectively, whereas $\mathrm{Th} 2$ and regulatory $\mathrm{T}$ cells (Tregs) produce anti-inflammatory cytokines, such as IL-10 [16-18]. Thus, the skewing toward Th1 and Th17 responses is responsible for the immune-mediated damage of myelin and axons [19].

The activation of CD4(+) T cells within the CNS leads to the recruitment of other inflammatory cells, such as B cells, which cross the $\mathrm{BBB}$, undergo activation, antigen-driven affinity maturation and clonal expansion [20]. In recent years, accumulated evidence emphasizes the role of B cells in the progression of MS [21, 22]. B cells are especially efficient in presenting antigens to $\mathrm{CD} 4(+) \mathrm{T}$ cells through HLA class II molecules [23]. Apart from antigen presentation, B cells are also able to produce autoantibodies after differentiation to plasma cells. Autoantibodies are able to cause demyelination through antibody-dependent cellular cytotoxicity (ADCC) and complement activation. Lastly, B cells are able to express pro-inflammatory cytokines, such as IL-6, IFN- $\gamma$ and TNF $\alpha$, known to be implicated in MS [24-26]. In particular, RRMS patients were found to have elevated peripheral expression of IFN- $\gamma$, interleukin (IL) 1-beta (IL1B), IL-7, IL-10, IL12A, IL-15, IL-23, IL-27, lymphotoxin-alpha (LTA) and lymphotoxin-beta (LTB) [27]. The main sources of pro-inflammatory cytokines within PBMCs were T- and B cells, whereas monocytes were the most noticeable source of immunoregulatory cytokines [27]. Hence, the inflammatory reaction of T, B and other immune cells leads to demyelinated lesions throughout the CNS [28]. Interestingly, healthy individuals also possess autoreactive $\mathrm{T}$ cells at lower frequencies, a finding which signifies that their presence is not enough per se for disease induction [29]. Thus, healthy individuals are likely to maintain regulatory mechanisms that keep these autoreactive $\mathrm{T}$ cells under control. Emerging evidence suggests that both Tregs and Bregs play a major role in this 'safeguard' process.

\section{Tregs}

Tregs were originally identified by Sakaguchi et al. in 1995 as a CD4(+)CD25(+) T cell subset with suppressive activity [30]. They are essential to the maintenance of self-tolerance and their impairment has been linked with autoimmunity and includes numerical decreases, functional defects and conversion into inflammatory effector cells [31]. High expression of CD25 and low expression of CD127 are the main phenotypic markers characterizing bona fide human Tregs [32]. CD25 (IL-2 receptor) is central to Treg ontogeny, optimal regulatory function and proliferation mediated by the gamma chain cytokines IL-2, IL-4, IL-7 and IL-15 [33]. Subsequently, it was shown that cells with regulatory capacity can also express CD8 [34], cytotoxic T-Lymphocyte antigen-4 (CTLA-4) [35, 36], the TCR-inducible costimulatory receptor (ICOS) [37] and high levels of CD5 $[38,39]$, a surface marker that instructs extrathymic Treg cell development in response to self and tolerizing antigens also co-expressed by certain B regulatory cell subsets [40, 41] (as discussed below). The seminal discovery of forkhead box P3 (FoxP3), as a fundamental transcription factor for the development of regulatory $\mathrm{CD} 4(+) \mathrm{CD} 25(+) \mathrm{T}$ cells in the thymus, helped researchers to precisely phenotype most Tregs [42]. FoxP3 (also known as Scurfin, IPEX, and JM2) is a transcriptional repression factor of the winged helix family and is expressed in all CD4(+) Treg cells with regulatory 
activity. Currently, Tregs may be accurately identified as CD4(+)CD25(+)FoxP3(+) T cells or (as FoxP3 inversely correlate with cell surface CD127 expression) as CD4(+) CD25(+)CD127(lo)/(-) T cells [43]. Specific regulatory T cell populations may also express other surface markers such as CD39, LAG-3 and GITR [44-47]

Natural and induced Tregs Tregs can be subdivided into thymus-developed, "natural" Tregs that mediate tolerance to self-antigens and "induced" Tregs derived from conventional CD4(+) T cells following non-self antigenic exposure [48]. Natural Treg production requires stable expression of FoxP3 and high-affinity binding of HLA/self-peptide complex on thymic antigen-presenting cells (APCs) to T cell receptor (TCR). Natural Tregs can be also sub-classified into CD45RA (+)"naïve" Tregs and CD45RO(+)"memory" Tregs [49]. 'Induced' or 'adaptive' Tregs (iTregs) are generated from naïve $T$ cells in the presence of transforming growth factor- $\beta$ (TGF- $\beta$ ) or retinoic acid and produce the anti-inflammatory cytokine IL-10 [50-52]. Despite the phenotypic and functional overlaps with natural Tregs, iTregs demonstrate apparent differences in stability and gene expression [53]. Type 1 regulatory $\mathrm{T}$ cells $(\mathrm{Tr} 1)$, are a subpopulation of Tregs-expressing CD4(+)CD49(+)LAG-3(+) IL-10(+) that exert significant immunosuppressive effects [54-56]. In addition, CD8(+) Tregs (Tr2) and IL-17-producing Tregs that share some common features with $\operatorname{Tr} 1$ also exist [57]. iTregs-expressing ROR $\gamma \mathrm{t}$, which is the master regulator of antimicrobial type 3 immunity are termed type 3 Tregs $(\operatorname{Tr} 3)[58,59]$. These cells constitute the major population of colonic Tregs, require bacterial antigens for differentiation and are distinct from thymus-derived Tregs.

Tregs function Tregs have a pivotal function in regulating the immune system by controlling the number and function of effector cells. Thus, they play a major role in suppressing unwanted autoreactive immune responses, such as in the case of autoimmunity [60]. Interestingly, it has been indicated that Tregs can modulate both adaptive and innate immune systems, and once activated they specifically regulate immune responses at multiple levels and by various mechanisms. These suppressive mechanisms can be organized into major groups, including cell-cell contactdependent suppression, inhibitory cytokine release (such as IL-10 and TGF- $\beta$ ), modulation of APC function, cytolysis, metabolic disruption and induction of suppressor cells or "infectious tolerance" [53].

In addition to IL-10, the inhibitory cytokine IL-35 also contributes to regulatory T cell function $[61,62]$. IL-35 belongs to IL-12 family of cytokines that includes IL-12, IL-23, IL-27 and IL-35. Of these, IL-12 and IL-23 have proinflammatory roles, whereas IL-35 appears to exert a more regulatory function by inducing the expansion of Tregs and
Bregs subsets and inhibiting Th17 cell differentiation [63]. IL-35-producing Tregs represent a distinct effector population from the IL-10-producing iTregs which also have different transcription factor dependency, as differentiation regulator Blimp1 is essential for IL-10 production, but not for IL-35, whereas Foxp3 is important for IL-35 but dispensable for IL-10 production [64]. Recently, it was demonstrated that the IL-12p35 alpha subunit of IL-35 efficiently suppressed encephalitogenic $\mathrm{T}$ cell responses and ameliorated experimental autoimmune encephalomyelitis (EAE), a wellcharacterized murine model of MS [65]. IL-12p35 inhibited the expansion of pathogenic Th17 and Th1 cells and mediated the expansion of Tregs and Bregs [65].

\section{Tregs and multiple sclerosis}

Major studies investigating the role of Tregs in MS are summarized in Table 1.

EAE mouse model The role of Tregs in MS has been thoroughly investigated in EAE [66]. EAE shares many features with the human disease and has thus revealed much information that led to the development of many approved therapies for MS $[67,68]$. A correlation was found between antigen-specific Tregs and disease resistance [69]; similarly, transfer of Tregs to EAE-induced mice reduced the severity of the disease [70]. In addition, depletion of CD25(+) T cells reduced the antigen burden required to induce $\mathrm{EAE}$ and prevented disease recovery [71]. Furthermore, Tregs were also involved in the regulation of cell transmigration across the BBB [72]. The EAE model system was also exploited for in vivo silencing of certain microRNAs such as miR26a, which increases the expression of Th17-related cytokines and establishes more severe EAE [73]. In contrast, overexpression of miR26a is associated with decreased expression of Th17-related cytokines, positive correlation with Treg FoxP3 and less severe disease [73].

Many treatment regimens increase Tregs and have also been proven quite successful at the experimental level (in EAE) [74]. For instance, IDO was shown to upregulate Tregs via tryptophan catabolite and to suppresses encephalitogenic $\mathrm{T}$ cell responses [75]. Further evidence suggested that vitamin A and its active metabolites (all-trans-retinoic acid and 9-cis-retinoic acid) could restore the imbalance of Th17 and Treg cells and can be considered as a promising target in the prevention of EAE [76]. Expansion of Tregs also appears promising. Lately, it was shown that engineered clonal MBP-specific Tregs ameliorated EAE in myelin oligodendrocyte glycoprotein (MOG)-immunized DR 15 transgenic mice [77]. Administration of antigen encapsulated within tolerogenic nanoparticles (tNPs) comprising biodegradable polymer is also capable of inducing Ag-specific Tregs [78]. 
Table 1 Main studies investigating the effect of MS-treated patients on regulatory B and T cells

\begin{tabular}{|c|c|c|c|c|}
\hline Authors, year of study & Origin/country & Treatment & Sample & Results \\
\hline Quan et al. (2015) & China & Rituximab & $\begin{array}{l}\text { Healthy controls }(n=19) \mathrm{NMO} \\
\text { patients }(n=9)\end{array}$ & $\begin{array}{l}\text { Tregs increased from } 0.3 \text { to } 1.2 \% \text { of total } \\
\text { lymphocytes after } 48 \text { weeks }\end{array}$ \\
\hline De Mercanti et al. (2016) & Europe & Alemtuzumab & RRMS patients $(n=29)$ & $\begin{array}{l}\text { Significant increase in CD4(+)CD25(hi) } \\
\text { CD127(lo)FoxP3(+) Tregs after } \\
24 \text { months of treatment }\end{array}$ \\
\hline Haas et al. (2015) & Germany & Fingolimod & $\begin{array}{l}\text { Healthy controls }(n=37) \mathrm{MS} \\
\text { patients }(n=74)\end{array}$ & $\begin{array}{l}\text { Increased median percentage of Tregs } \\
\text { from } 3 \text { to } 6,7 \% \text { after } 3 \text { months of treat- } \\
\text { ment }\end{array}$ \\
\hline Blumenfeld et al. (2016) & Israel & Fingolimod & MS patients $(n=10)$ & $\begin{array}{l}\text { Increase in the percentage of CD38(hi) } \\
\text { CD24(hi) "transitional" Bregs from } 3.7 \\
\text { to } 11.6 \%\end{array}$ \\
\hline Piancone et al. (2016) & Italy & Fingolimod & RRMS patients $(n=12)$ & $\begin{array}{l}\text { Significant increase in CD19(+) } \\
\text { BTLA(+)IL-10(+) B cells both as a } \\
\text { percentage of total lymphocytes and } \\
\text { CD19(+) B cells }\end{array}$ \\
\hline Lundy et al. (2016) & USA & Dimethyl Fumarate & RRMS patients $(n=13)$ & $\begin{array}{l}\text { After } 12 \text { months of treatment: CD19(+) } \\
\text { B cells concentration was halved and } \\
\text { CD24(hi)CD38(hi) Bregs were doubled }\end{array}$ \\
\hline Stenner et al. (2008) & Germany & Natalizumab & RRMS patients $(n=15)$ & $\begin{array}{l}\text { No significant change in Tregs percent- } \\
\text { age } 30 \text { days after initiation of therapy }\end{array}$ \\
\hline Putzki et al. (2010) & Switzerland & Natalizumab & RRMS patients $(n=28)$ & $\begin{array}{l}\text { Relative decrease in CD } 4(+) \text { CD25 }(+) \\
\text { Tregs from } 18.9 \text { to } 14.1 \%\end{array}$ \\
\hline Schubert et al. (2015) & USA & IFN- $\beta$ & $\begin{array}{l}\text { Treatment-naïve RRMS patients } \\
(n=10) \text { IFN- } \beta \text {-treated RRMS } \\
\text { patients }(n=11)\end{array}$ & $\begin{array}{l}\text { Increase in CD24(hi)CD38(hi) "transi- } \\
\text { tional" Bregs from } 1.09 \text { to } 9.50 \%\end{array}$ \\
\hline Ireland et al. (2014) & USA & Glatiramer acetate & $\begin{array}{l}\text { Treatment-naïve MS patients } \\
(n=22) \text { Glatiramer acetate-treated } \\
\text { MS patients }(n=22)\end{array}$ & $\begin{array}{l}\text { Treated patients IL- } 10 \text { production by B } \\
\text { cells was equivalent to those in healthy } \\
\text { donors and up to } 6.5 \text {-fold greater than } \\
\text { the levels in treatment-naive patients }\end{array}$ \\
\hline
\end{tabular}

tNP-treated mice did not develop EAE following adoptive transfer of encephalitogenic T cells [78].

Human MS It has become apparent that Tregs are also implicated in the pathophysiology of MS in humans [53, 74]. Although increased frequencies of Tregs are found in the cerebrospinal fluid but not peripheral blood of MS patients [79], alterations in Treg homeostasis [80, 81] and their functional impairment are documented [82-84]. Interestingly, their functional defects are more profound in RRMS than in SPMS $[85,86]$. Analysis of the thymic export activity in MS patients revealed impaired release of newly formed $\mathrm{T}$ cells into the periphery resulting in an imbalance of circulating Tregs [87]. This thymic functional impairment is compensated by peripheral post-thymic expansion, creating a shift from naïve Tregs to memory Tregs in MS patients. Researchers argue that this shift may account for the impaired suppressive function of Tregs in MS.

Another possible mechanism for the functional failure of Tregs appears to be pro-inflammatory cytokines, such as IL-12, which are up-regulated in MS [88]. IL-12 has the ability to change the phenotype and function of Tregs by inducing IFN- $\gamma$ production. IFN- $\gamma$-producing Tregs display a decline in their suppressive activity in vitro, as IFN- $\gamma$ blockade significantly boosted their suppressive ability but did not affect control Tregs [89]. The increased percentages of Th1-like Tregs may partly account for the lack of suppressive function Tregs of MS patients. These data illustrate the phenomenon of enhanced Tregs plasticity toward a pro-inflammatory, cytokine-producing effector phenotype [90]. Skewed IFN- $\gamma$-producing Th1-like Tregs play significant role in MS and also other autoimmune diseases [53, 91] and malignancies [92]. Importantly, IL-12 dependent IFN- $\gamma$ production of Tregs could also be mimicked in vitro in Tregs from healthy subjects creating Th1-like Tregs that resembled a classical Th1 phenotype [89]. Moreover, Th17-like Tregs which expanded in the presence of IL- 6 and IL- $1 \beta$ have also been documented [93, 94].

Apart from FoxP3(+) Tregs, the role of Tr1 cells' role in MS seems to be equally important. In MS, Tr1 cells were reduced in CD46-activated T cells [83], which are known to acquire a $\operatorname{Tr} 1$ phenotype [95]. Furthermore, IL-10 production from CD46- activated T cells was almost absent, while IFN- $\gamma$ production was not affected in these cells. It can, therefore, be concluded from these findings that MS is 
associated with multiple defects in regulatory $\mathrm{T}$ cell populations [83].

\section{Bregs}

Bregs are a subset of B cells that display suppressive functions toward pro-inflammatory and autoreactive immune responses. They express IL-10 and other regulatory cytokines such as TGF- $\beta$ and IL-35 that limit inflammation $[63,96-98]$. On the other hand, an overly suppressed immune system is vulnerable to infection or cancer, so a balanced number and function of Bregs is essential [99, 100].

\section{Phenotype}

Despite extensive research on Bregs in recent years, to date there is no consensus on a specific Breg phenotype [101]. Although there is a number of identifiable Breg subsets, it is still not known if they are developed from a distinct cell lineage, like thymus-derived Tregs, or are induced by immunological triggers [102]. On a similar note, no Breg-specific transcription factor has been identified. Although expression of Foxp3 by certain Bregs is documented [103], it is still a matter of debate whether B cell-specific expression of FoxP3 facilitates acquisition of suppressive capacity. Due to the lack of molecular markers, Bregs are usually identified by their ability to express IL-10, and these are termed B10 cells. In humans, both "naïve" CD19(+)CD24(hi)CD38(hi) [104] and "memory" CD19(+)CD24(hi)CD27(+) [105] Bregs have been identified as the principal IL-10-expressing subsets [106]. Bregs also express high levels of CD5 [107-109], while CD5(+)IL-35-producing Bregs and TGF $\beta$-producing Bregs have also been described [110,111]. Furthermore, B cells with regulatory function can also express CD25 and LAG-3, similarly to Tregs [112, 113]. Moreover, Bregs such as CD73(-)CD25(+)CD71(+) BR1 subsets of plasma cells are associated with anti-inflammatory IgG4 antibody secretion which is important for allergic airway inflammation $[114,115]$. This illuminates a further immune-regulatory role of the non-inflammatory and blocking antibody function of $\mathrm{IgG} 4$, which may require further investigation.

\section{Bregs function}

Bregs suppress the pro-inflammatory cytokine production by dendritic cells, leading to inhibition of Th1 and Th17 differentiation [116]. Bregs have also been documented to support in vivo Tregs expansion in both mice and humans $[104,117]$. In several reports, flow cytometry and/or magnetically sorted CD4(+) T cells were co-cultured with autologous Bregs to elucidate the effector mechanisms of Bregs on CD4(+) T cells, including the generation of suppressive Tregs [118-120]. In co-culture with Bregs, CD4(+)
CD25(-) T cells produced less IFN- $\gamma$ and IL-17, whereas Treg induction was predominantly facilitated by expression of IL-10 and TGF- $\beta$. All these studies confirmed previous data from murine systems where naïve $\mathrm{T}$ cells co-cultured with a mixture of APCs consisting of B and dendritic cells in the presence of TGF- $\beta$, retinoic acid and IL-2, differentiated into allogeneic Tregs [121]. In addition, through the expression of TGF- $\beta$, lipopolysaccharide (LPS)-activated B cells can promote both the apoptosis of CD4(+) [122] and anergy in CD8(+) [123] effector T cells.

(a) $B 10 \mathrm{~B} 10$ is a Breg subset whose regulatory function is entirely attributed to their IL-10 production. Moreover, this suppressive function seems to be antigen specific, most likely due to antigen-specific B cell receptor (BCR) signaling $[124,125]$. This BCR specificity explains the rapid $\mathrm{B} 10$ response to antigens, self- or otherwise, rendering them capable of suppressing unwanted excessive immune responses [reviewed by [126] ].

(b) IL-10 independent Bregs A novel CD138(+)IL-35(+) Breg (i35 Breg) population has been characterized recently, which produces IL-35, apart from IL-10. Through IL-35 expression, these cells regulate CNS inflammation. IL-35 has the ability to transform conventional B cells or B10 cells to IL-35-expressing i35-Bregs [reviewed by [127] ]. Furthermore, TGF- $\beta$ expressing Bregs are thought to play a role in the suppression of allergic reactions. They evidently promote Treg differentiation by upregulating FoxP3 production in $\mathrm{T}$ cells and regulate food allergy-induced inflammation in mice. In addition, thrombospondin 1-secreting CD35(+) B cells induced a Treg phenotype through TGF- $\beta$, but not IL-10 and suppressed co-stimulatory molecule expression on dendritic cells. Moreover, there is evidence that PD-L1 (programmed death 1) is involved in Bregs function, as $\mathrm{PD}-\mathrm{L} 1^{\mathrm{Hi}} \mathrm{B}$ cells negatively regulate $\mathrm{T}$ cell differentiation [128] (reviewed by [129]).

(c) BTLA-expressing Bregs $\mathrm{B}$ and $\mathrm{T}$ lymphocyte attenuator (BTLA or CD272) is an immunoglobulin, which, like programmed death-1 (PD-1), is involved in the suppression of immune responses. BTLA contains two immunoreceptor tyrosine-based inhibitory motifs (ITIM) and is expressed on a wide range of immune cells including T and B lymphocytes, NKT cells, NK cells, macrophages, dendritic cells [130] and follicular Th1 cells [131].

\section{Bregs and multiple sclerosis}

EAE mouse model $B$ cells can play a regulatory role in EAE pathophysiology, as mice with genetically deficient B 
cells cannot recover from the disease, whereas transfer of IL-10-producing B cells suppresses EAE symptoms [124, 125]. For instance, Bregs, transduced into mice with EAE, accumulated in the spleen and mesenteric lymph nodes, leading to an expansion of Tregs and $\operatorname{Tr} 1$ cells in vivo [132]. Importantly, Tregs and Tr1 s were also enriched in the CNS of the same littermates. In the EAE model again, treatment with MOG protein fused to reovirus protein $\sigma 1$ (MOG-p $\sigma 1$ ), resulted in an expansion of IL-10-producing B220(+)CD5(+) Bregs, which restored Tregs and facilitated the rapid improvement of EAE [133]. Additionally, PD-L1 ${ }^{\mathrm{Hi}}$ Bregs transferred to afflicted animals suppressed the disease. In total, Bregs, in contrast to effector B cells, protect from the development of EAE, by suppressing proinflammatory cytokines and the transmigration of activated cells to the CNS $[97,134,135]$.

Human MS There is no consensus on Breg numbers in autoimmune diseases. In most diseases or disease states, Bregs are reduced [136-140] but increased numbers were also reported [105]. In MS in particular, Bregs are reported to be numerically decreased [141, 142], unaltered [143, 144] or increased [145]. A representative phenotypic flow cytometric analysis of Bregs in RRMS is shown in Fig. 1. Irrespective of their numbers, Bregs function is impaired in MS patients, as IL-10 production and suppressive function of B cells are reduced [21, 146-148]. In addition, the proportion of naïve Bregs in disease relapses is reduced, leading to an increased memory/naïve ratio [141]. Whether this reduction is the cause or the consequence of disease relapse remains to be seen. Recent data also have indicated that reduced peripheral blood Breg levels were not associated with the Expanded Disability Status Scale score in MS [149].

A novel type of Bregs, CD19(+)CD25(+) cells, was described in both healthy subjects and MS patients [112, 145]. This new subtype seems to be numerically increased in

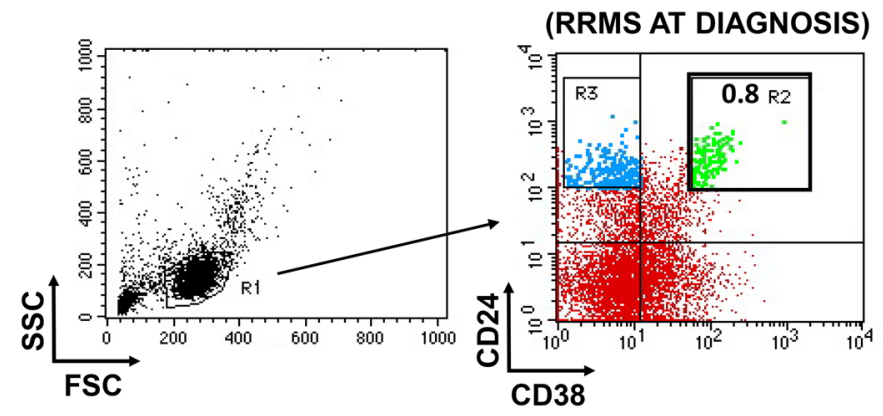

Fig. 1 Typical flow cytometric analysis of memory and transitional Bregs in RRMS. PBMCs from representative patients with RRMS at diagnosis, relapse and remission were stained with CD19, CD24, CD27 and CD38 moAbs and analyzed by flow cytometry. Total lymphocytes were gated based on forward-side scatter characteristic excluding dead cells and debris (gate R1). Transitional Bregs were
MS compared to healthy controls, and also in relapse compared to disease remission [135]. It is apparent that much more research is needed to illuminate the role of different Breg subsets in MS [150].

\section{Effects of MS therapies on Tregs and Bregs}

\section{Monoclonal antibodies}

Anti-CD20 B cell-depleting therapies in MS focus on two main targets, CD20 and CD19. Monoclonal anti-CD20 includes rituximab, ocrelizumab and ofatumumab, which differ in their CD20 epitope recognition and in the intensity of their action [151]. CD20 is expressed on most B cells, from PreB to IgG memory B cells, while leaving plasmablasts and ProB cells mostly lack expression. All anti-CD20 therapies cause an almost complete extinction of B cell subtypes in peripheral blood [152]. B cell repopulation begins several months post-treatment and appears to be inclined toward a more naïve and regulatory phenotype [153]. B cell depletion also suppresses $\mathrm{T}_{\mathrm{H}} 1$ and $\mathrm{T}_{\mathrm{H}} 17$ responses and increases circulating Tregs. In general, this therapy has shown to ameliorate disease symptoms and activity, and reduce relapse rate, including reduction in gadoliniumenhancing lesions on brain MRI $[154,155]$.

Anti-CD19 Anti-CD19 monoclonal therapy also looks promising. IgG1 anti-CD19 antibody (MEDI-551) [156] recently entered a phase II clinical trial in MS. CD19 is expressed on all B cells and is progressively lost in terminally differentiated plasma cells [157]. As a result, it comes as no surprise that MEDI-551 induced a longer-lasting B cell depletion than rituximab, while also reducing immunoglobulin serum levels, including autoantibodies [155]. Anti-CD19 therapy in EAE-induced mice suppressed disease severity and duration and increased circulating Tregs, whereas potentially
(RRMS AT RELAPSE)

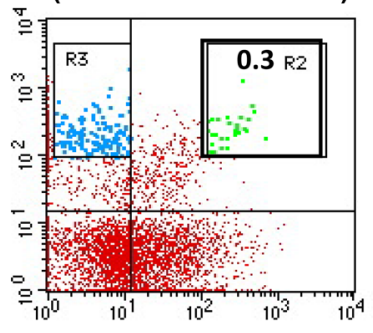

(RRMS AT REMISSION)

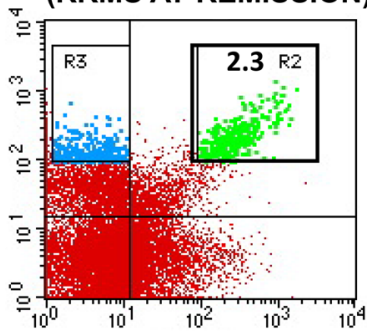

identified based on high expression of CD38 and CD24 markers (green color-gate R2) and positivity for CD19. Memory Bregs were identified based on high expression of CD24, positivity for CD19, CD27 markers and lack of CD38 expression (blue color-gate R3). At remission, transitional Bregs appear significantly increased 
protective CD1d(hi)CD5(+) Bregs displayed resistance to depletion [158]. Hence, MEDI-551 is expected to have similar effects to anti-CD20 therapy on MS patients and could be approved for the treatment of MS in the future especially targeting autoreactive $\mathrm{CD} 19(+) \mathrm{CD} 20(-)$ plasma cells that would be resistant to CD20 mAb treatment [159].

Alemtuzumab Alemtuzumab is a humanized IgG1 monoclonal antibody that targets the CD52 (Campath-1 antigen), a 12 amino acid glycoprotein anchored to glycosylphosphatidylinositol, which is widely expressed on the cell surface of mature immune cells. Anti-CD52 induces a rapid and prolonged depletion of lymphocytes from the circulation, which results in a profound immunosuppression status followed by an immune reconstitution phase [160]. In EAE, anti-CD52 treatment abrogated B cell infiltration and disrupted existing B cell aggregates in the CNS [161]. Recently, it has been shown that it can also ameliorate colitis through suppressing Th1/17 mediated inflammation and promoting Tregs differentiation in IL-10 deficient mice [162]. Much of the research on alemtuzumab focuses on the lymphocyte repopulation progress and shows that CD4(+) CD25(+)CD127(low) Treg cells preferentially expand within the $\mathrm{CD} 4(+)$ lymphocytes, reaching their peak within 1 month [163]. A recent study demonstrated that alemtuzumab increased anti-inflammatory cytokines (such as IL-10 and TGF- $\beta$ ) while diminishing pro-inflammatory cytokines (such as IFN- $\gamma$, IL-17, IL-6 and TNF- $\alpha$ ) within 6 months of treatment and increased Tregs percentage and function after 24 months post-treatment [164]. In addition, alemtuzumab seems to affect $B$ cells, as it increased the percentage of repopulated naïve/immature B cells [165, 166]. Alemtuzumab may thus be a promising therapy for MS [6]; however, it also causes loss of immune-tolerance leading to secondary autoimmunity such as Graves' disease and marked anti-drug antibody responses [160, 167].

Natalizumab Natalizumab, approved for the treatment of MS, is a humanized IgG4 monoclonal antibody. It mainly binds to the $\alpha 4$-chain of $\alpha 4 \beta 1$ integrin heterodimer-also known as very late activating antigen-4 (VLA-4), on the surface of leucocytes and inhibits binding of VLA-4 to vascular cell adhesion molecule-1 (VCAM-1) and, consequently, the attachment of leucocytes to the inner lining of cerebral vascular walls and their crossing of the BBB. This crossing directly diminishes IgM and partially IgG in the CSF [168] as well as in the serum [169]. Thus, natalizumab modulates B cell functions, but appears to be unable to restore the suppressive function of Tregs while marginally decreasing their percentages in MS [170, 171].

Tocilizumab Tocilizumab is a humanized IgG1 anti-IL-6 receptor monoclonal antibody approved by the FDA for the treatment of rheumatoid arthritis, active systemic juvenile idiopathic arthritis and polyarticular juvenile idiopathic arthritis. IL-6 is known to induce plasmablast production of anti-aquaporin 4 (Aqp-4) antibodies in vitro and may account for neuromyelitis optica (NMO) disease activity [172]. IL-6 concentration is increased in the CSF of NMO patients [173] and IL-6 induces pro-inflammatory Th17 cells in both NMO and MS patients [174]. Thus, tocilizumab modulates Th17 cells and plasmablasts. Although there are no data on its effect on Tregs and Bregs, tocilizumab appears to be an attractive candidate therapeutic agent for MS.

\section{Other immunomodulatory agents}

Fingolimod Fingolimod is an approved therapeutic agent for RRMS. It has a potent pharmacological action because it functions as an unselective agonist of sphingosine 1-phosphate receptors (S1PR) and as a selective antagonist of the S1P1 subtype by induction of receptor downregulation [175]. Since S1P1 is fundamental in the regulation of lymphocyte trafficking, its downregulation leads to redistribution of the immune cells to secondary lymphoid tissues, resulting in the depletion from the circulation and therefore immunosuppression [175]. It prevents lymphocyte egress from secondary lymphoid tissues, promoting loss of CCR7expressing $\mathrm{T}$ cells and increase in Treg numbers and their suppressive function on $\mathrm{T}$ cell proliferation $[176,177]$. It may affect $\mathrm{B}$ cells, as it leads to increased percentage of plasma cells and a shift toward a more naïve and transitional B cell phenotype. In addition, treatment with fingolimod increases both Breg numbers and function, indicated by a boost in IL-10 production [8]. According to recent data, fingolimod significantly enhances CD19(+)BTLA(+) IL-10(+) B cells in RRMS patients, which may relate to amelioration of symptoms [142].

Dimethyl fumarate Dimethyl fumarate (DMF) is an approved therapeutic agent for MS. Its in vivo metabolite monomethyl fumarate (MMF) can bind to brain endothelium cells leading to activation of nuclear factor (erythroidderived 2)-related factor 2 (Nrf2) and downregulation of vascular cell adhesion molecule 1 (VCAM-1) [178].This can be mediated via the G-protein-coupled receptor (GPCR) hydroxycarboxylic acid receptor 2 (HCA2), a known molecular target of MMF. Studies have documented the binding of DMF to HCA2 on dendritic cells followed by the inhibition of pro-inflammatory cytokines production in vitro and in MS murine models [179]. Although its precise mechanism of action remains unclear, evidence indicates that activation of HCA2/GPR109A pathway can decrease immune responses and may enhance anti-inflammatory functions in the intestinal mucosa, possibly leading to reduction in CNS tissue damage in MS patients [180]. In addition, it causes 
depletion of circulating lymphocytes in peripheral blood [181, 182]. More precisely, DMF alters lymphocyte subsets homeostasis in MS patients, decreasing absolute lymphocyte counts, but does not affect all subsets uniformly [183]. $\mathrm{CD} 8(+) \mathrm{T}$ cells are mainly affected, with reductions in the CD4(+) cells, particularly within the pro-inflammatory T-helper Th1 and Th17 subsets also occurring, creating a bias toward more anti-inflammatory $\mathrm{Th} 2$ and regulatory subsets [183]. Both naïve and memory B cells were diminished in certain patients, while Bregs were increased after 4-6 months of therapy and remained in higher numbers at 12 months post-treatment. Also, IL-10 production was elevated in some patients [184]. Other studies showed a skewing from memory CD8(+) and CD4(+) T cells toward their naïve counterparts together with a curtail on $\mathrm{T}_{\mathrm{H}} 1$ cells in dimethyl fumarate-treated RRMS patients [9] and an antiInflammatory shift in B Cell subsets $[183,185]$. These limited data appear very promising.

Teriflunomide Teriflunomide is an approved oral therapeutic agent for MS relapses. Its main mechanism of action involves the suppression of the de novo synthesis of pyrimidines in rapidly proliferating cells such as $\mathrm{T}$ and $\mathrm{B}$ lymphocytes [186]. Pyrimidine synthesis inhibition leads to halt of the cell cycle in G1 phase and it thus has anti-proliferative results, reducing autoantigen-specific immune responses. In a recent study of teriflunomide in murine EAE, a significant increase in CD39(+) Treg concentration was observed, along with decrease in APCs of Peyer patches [187] [reviewed by [10] ].

Glatiramer acetate Glatiramer acetate (GA), a random polymer consisting of four amino acids of the myelin basic protein, is considered a first-line treatment for MS. It prevents disease relapses and patient disability. This agent shifts $\mathrm{T}$ cells from a $T_{H} 1$ to a $T_{H} 2$ response [188, 189]. GA induces a Treg phenotype and increases FoxP3 expression while restoring Treg function [190]. B cells from GA-treated EAE mice also increased production of IL-10 and reduced expression of co-stimulatory molecules [191]. Importantly, the therapeutic effect of GA in EAE was abrogated in B celldeficient mice [191, 192]. Another study demonstrated that B cell IL-10 expression was restored, and IL- 6 production was diminished after glatiramer acetate treatment. There was also altered proliferation in response to $\mathrm{CD} 40 \mathrm{~L}$ and an increased immunoglobulin production by B cells [193].

Ifn IFN $\beta-1 b$ and IFN $\beta-1 a$ are disease-modifying agents for RRMS, affecting multiple immunological processes. IFN $\beta$ suppresses the ability of APCs to present antigens and stimulate $T$ cells [194] and prevents $T$ cells from crossing the BBB, while channeling autoreactive $T$ cells into lymphoid tissues [195]. In addition, IFN $\beta$ has the ability to induce Tregs, probably due to a shift to Tregpromoting cytokines, such as IL-4, IL-5 and IL-13 [195]. Transitional Bregs are thought to increase as well, as a result of IFN- $\beta$ therapy $[24,196]$. Moreover, the treatment causes Th17 death [197], reduces TNF and increases IL-27 production, known to slow down EAE progression. Thus, IFN- $\beta$ therapy both impedes pro-inflammatory cells and cytokines and promotes anti-inflammatory ones in MS (Reviewed by [198]).

Statins Apart from specialized therapies, there are other agents with immunomodulatory properties that could prove useful as supportive and/or complementary treatments for MS. One example is HMG-CoA reductase inhibitors (statins), which are a class of lipid-lowering medications known to have immunomodulatory properties. For instance, atorvastatin increases Tregs and reduces clinical disease activity in patients with rheumatoid arthritis. It also displayed anti-inflammatory effects on peripheral blood [199]. In a recent study, atorvastatin and lovastatin enhanced Tregs numbers, but also FoxP3 mRNA levels 30 days post-treatment. However, Treg numbers returned to standard levels after 45 days of treatment. Nevertheless, increased values of TGF- $\beta$, FoxP3, CTLA- 4 and GITR-expressing Tregs were observed [200]. Simvastatin also regulated TGF- $\beta$ signal transduction, leading to an increase of Tregs [201], and reduced pro-inflammatory cytokines in patients with rheumatoid arthritis. Statins have an effect on MS as well. Simvastatin suppressed mononuclear cell responses, reduced IFN- $\gamma$, TNF- $\alpha$ and IL-2 production and inhibited the antigen-presenting capacity of macrophages [202]. Furthermore, atorvastatin combined with glatiramer acetate showed synergistic immunomodulatory effects in MS [203].

Vitamin D Vitamin D or 25-hydroxy vitamin D $(25(\mathrm{OH})$ D) - the main vitamin D metabolite measured in bloodis known to have immunomodulatory properties. Vitamin $\mathrm{D}$ affects both $\mathrm{B}$ and $\mathrm{T}$ lymphocytes. It inhibits $\mathrm{T}$ cell proliferation and reduces IFN- $\gamma$, IL- 2 and IL-17 expression [204], while increasing IL-10 and Tregs [205]. It also inhibits plasma cell production and increases IL10-Bregs. Recent evidence from the EAE mouse model indicated that vitamin D-induced dendritic cells could ameliorate symptoms by enhancing the proportions of regulatory lymphocytes and reducing T-helper type 1 and type 17 cells [206]. Vitamin D deficiency is associated with an increased incidence of MS [207]. During MS relapse, 25(OH)D levels are generally decreased [208]. In a small study, vitamin D supplementation led to a significant reduction of the number of newly active brain lesions [209] (reviewed by [210]). 


\section{Conclusion}

Multiple sclerosis is the most prevalent autoimmune disease of the CNS and a frequent cause of neurological disability in young adults. As there is no cure for the disorder, the aim of new treatments is the alleviation of symptoms and the reduction of relapses. As with most autoimmune diseases, MS patients exhibit impaired immunoregulatory mechanisms that lead to harmful immune responses. It is not yet recognized whether this dysregulation is the cause or a consequence of the disease. Nevertheless, regulatory mechanisms play a major role in MS. Thus, it comes as no surprise that most if not all of MS therapies have immunomodulatory actions. It is important to conduct more research on current medications and their influence on regulatory lymphocytes to uncover their exact mechanism of action and to be able to administer the appropriate therapeutic agent to each patient, according to their particular condition (personalized or precision medicine). On a final note, other agents that are not currently in use in MS but have immunomodulatory properties, such as vitamin D or statins, could be beneficial as a complementary treatment for MS.

\section{Compliance with ethical standards}

\section{Conflict of interest None.}

Human and animal rights This article does not contain any studies with animals performed by any of the authors.

Informed consent This article does not require informed consent due to the lack of human participants.

Open Access This article is distributed under the terms of the Creative Commons Attribution 4.0 International License (http://creativeco mmons.org/licenses/by/4.0/), which permits unrestricted use, distribution, and reproduction in any medium, provided you give appropriate credit to the original author(s) and the source, provide a link to the Creative Commons license, and indicate if changes were made.

\section{References}

1. Compston A, Coles A (2008) Multiple sclerosis. Lancet 372(9648):1502-1517

2. Giovannoni G, Miller DH (1999) Multiple sclerosis and its treatment. J R Coll Physicians Lond 33(4):315-322

3. Francis DA (2001) Glatiramer acetate (Copaxone). Int J Clin Pract 55(6):394-398

4. Signori A, Gallo F, Bovis F, Di Tullio N, Maietta I, Sormani MP (2016) Long-term impact of interferon or Glatiramer acetate in multiple sclerosis: a systematic review and meta-analysis. Mult Scler Relat Disord 6:57-63
5. Castillo-Trivino T, Braithwaite D, Bacchetti P, Waubant E (2013) Rituximab in relapsing and progressive forms of multiple sclerosis: a systematic review. PLoS One 8(7):e66308

6. Havrdova E, Horakova D, Kovarova I (2015) Alemtuzumab in the treatment of multiple sclerosis: key clinical trial results and considerations for use. Ther Adv Neurol Disord 8(1):31-45

7. Coles AJ (2013) Alemtuzumab therapy for multiple sclerosis. Neurotherapeutics 10(1):29-33

8. Blumenfeld S, Staun-Ram E, Miller A (2016) Fingolimod therapy modulates circulating B cell composition, increases B regulatory subsets and production of IL-10 and TGFbeta in patients with multiple sclerosis. J Autoimmun 70:40-51

9. Gross CC, Schulte-Mecklenbeck A, Klinsing S, Posevitz-Fejfar A, Wiendl H, Klotz L (2016) Dimethyl fumarate treatment alters circulating $\mathrm{T}$ helper cell subsets in multiple sclerosis. Neurol Neuroimmunol Neuroinflammation 3(1):e183

10. Oh J, O'Connor PW (2014) Teriflunomide in the treatment of multiple sclerosis: current evidence and future prospects. Ther Adv Neurol Disord 7(5):239-252

11. Sabatino JJ, Zamvil SS, Hauser SL (2018) B-Cell therapies in multiple sclerosis. Cold Spring Harb Perspect Med. https://doi. org/10.1101/cshperspect.a032037

12. Midaglia L, Mora L, Mulero P, Sastre-Garriga J, Montalban X (2018) Rituximab: its efficacy, effectiveness and safety in the treatment of multiple sclerosis. Rev Neurol 66(1):25-32

13. Sokratous M, Dardiotis E, Tsouris Z, Bellou E, Michalopoulou A, Siokas V et al (2016) Deciphering the role of DNA methylation in multiple sclerosis: emerging issues. Auto Immun Highlights 7(1):12

14. Baecher-Allan C, Kaskow BJ, Weiner HL (2018) Multiple sclerosis: mechanisms and immunotherapy. Neuron 97(4):742-768

15. Naegele M, Martin R (2014) The good and the bad of neuroinflammation in multiple sclerosis. Handb Clin Neurol 122:59-87

16. Hedegaard CJ, Krakauer M, Bendtzen K, Lund H, Sellebjerg F, Nielsen CH (2008) T helper cell type 1 (Th1), Th2 and Th17 responses to myelin basic protein and disease activity in multiple sclerosis. Immunology 125(2):161-169

17. Drulovic J, Savic E, Pekmezovic T, Mesaros S, Stojsavljevic N, Dujmovic-Basuroski I et al (2009) Expression of Th1 and Th17 cytokines and transcription factors in multiple sclerosis patients: does baseline T-bet mRNA predict the response to interferonbeta treatment? J Neuroimmunol 215(1-2):90-95

18. Peelen E, Damoiseaux J, Smolders J, Knippenberg S, Menheere $\mathrm{P}$, Tervaert JW et al (2011) Th17 expansion in MS patients is counterbalanced by an expanded CD39+regulatory T cell population during remission but not during relapse. J Neuroimmunol 240-241:97-103

19. Loma I, Heyman R (2011) Multiple sclerosis: pathogenesis and treatment. Curr Neuropharmacol 9(3):409-416

20. von Budingen HC, Kuo TC, Sirota M, van Belle CJ, Apeltsin L, Glanville J et al (2012) B cell exchange across the blood-brain barrier in multiple sclerosis. J Clin Investig 122(12):4533-4543

21. Staun-Ram E, Miller A (2017) Effector and regulatory B cells in multiple sclerosis. Clin Immunol 184:11-25

22. Sospedra M (2018) B cells in multiple sclerosis. Curr Opin Neurol 31(3):256-262

23. Batista FD, Harwood NE (2009) The who, how and where of antigen presentation to B cells. Nat Rev Immunol 9(1):15-27

24. Meinl E, Krumbholz M, Hohlfeld R (2006) B lineage cells in the inflammatory central nervous system environment: migration, maintenance, local antibody production, and therapeutic modulation. Ann Neurol 59(6):880-892

25. Barr TA, Shen P, Brown S, Lampropoulou V, Roch T, Lawrie $S$ et al (2012) B cell depletion therapy ameliorates autoimmune disease through ablation of IL-6-producing B cells. J Exp Med 209(5):1001-1010 
26. Mielle J, Audo R, Hahne M, Macia L, Combe B, Morel J et al (2018) IL-10 producing B cells ability to induce regulatory T cells is maintained in rheumatoid arthritis. Front Immunol 9:961

27. Romme Christensen J, Bornsen L, Hesse D, Krakauer M, Sorensen PS, Sondergaard HB et al (2012) Cellular sources of dysregulated cytokines in relapsing-remitting multiple sclerosis. J Neuroinflammation 9:215

28. Claes N, Fraussen J, Stinissen P, Hupperts R, Somers V (2015) $\mathrm{B}$ cells are multifunctional players in multiple sclerosis pathogenesis: insights from therapeutic interventions. Front Immunol 6:642

29. Nylander A, Hafler DA (2012) Multiple sclerosis. J Clin Investig 122(4):1180-1188

30. Sakaguchi S, Sakaguchi N, Asano M, Itoh M, Toda M (1995) Immunologic self-tolerance maintained by activated $\mathrm{T}$ cells expressing IL-2 receptor alpha-chains (CD25). Breakdown of a single mechanism of self-tolerance causes various autoimmune diseases. J Immunol 155(3):1151-1164

31. Grant CR, Liberal R, Mieli-Vergani G, Vergani D, Longhi MS (2015) Regulatory T-cells in autoimmune diseases: challenges, controversies and-yet-unanswered questions. Autoimmun Rev 14(2):105-116

32. Su H, Longhi MS, Wang P, Vergani D, Ma Y (2012) Human CD4+CD25(high)CD127 (low/neg) regulatory T cells. Methods Mol Biol 806:287-299

33. Yates J, Rovis F, Mitchell P, Afzali B, Tsang J, Garin M et al (2007) The maintenance of human CD4+CD25+ regulatory T cell function: IL-2, IL-4, IL-7 and IL-15 preserve optimal suppressive potency in vitro. Int Immunol 19(6):785-799

34. Lee J, Park N, Park JY, Kaplan BLF, Pruett SB, Park JW et al (2018) Induction of immunosuppressive CD8(+)CD25(+) FOXP3(+) regulatory $\mathrm{T}$ cells by suboptimal stimulation with staphylococcal enterotoxin C1. J Immunol 200(2):669-680

35. Saverino D, Simone R, Bagnasco M, Pesce G (2010) The soluble CTLA-4 receptor and its role in autoimmune diseases: an update. Auto Immun Highlights 1(2):73-81

36. Takahashi T, Tagami T, Yamazaki S, Uede T, Shimizu J, Sakaguchi $\mathrm{N}$ et al (2000) Immunologic self-tolerance maintained by CD25(+)CD4(+) regulatory $\mathrm{T}$ cells constitutively expressing cytotoxic $\mathrm{T}$ lymphocyte-associated antigen 4. J Exp Med 192(2):303-310

37. Qiao YC, Pan YH, Ling W, Tian F, Chen YL, Zhang XX et al (2017) The Yin and Yang of regulatory T cell and therapy progress in autoimmune disease. Autoimmun Rev 16(10):1058-1070

38. Henderson JG, Opejin A, Jones A, Gross C, Hawiger D (2015) CD5 instructs extrathymic regulatory $\mathrm{T}$ cell development in response to self and tolerizing antigens. Immunity 42(3):471-483

39. Ono M, Tanaka RJ (2016) Controversies concerning thymusderived regulatory $\mathrm{T}$ cells: fundamental issues and a new perspective. Immunol Cell Biol 94(1):3-10

40. Xing C, Ma N, Xiao H, Wang X, Zheng M, Han G et al (2015) Critical role for thymic CD19+CD5+CD1dhilL-10+ regulatory B cells in immune homeostasis. J Leukoc Biol 97(3):547-556

41. Zheng M, Xing C, Xiao H, Ma N, Wang X, Han G et al (2014) Interaction of CD5 and CD72 is involved in regulatory $\mathrm{T}$ and $\mathrm{B}$ cell homeostasis. Immunol Invest 43(7):705-716

42. Fontenot JD, Gavin MA, Rudensky AY (2003) Foxp3 programs the development and function of CD4+CD25+ regulatory $\mathrm{T}$ cells. Nat Immunol 4(4):330-336

43. Devaud C, Darcy PK, Kershaw MH (2014) Foxp3 expression in $\mathrm{T}$ regulatory cells and other cell lineages. Cancer Immunol Immunother CII 63(9):869-876

44. Borsellino G, Kleinewietfeld M, Di Mitri D, Sternjak A, Diamantini A, Giometto R et al (2007) Expression of ectonucleotidase CD39 by Foxp3+Treg cells: hydrolysis of extracellular ATP and immune suppression. Blood 110(4):1225-1232
45. Okamura T, Fujio K, Shibuya M, Sumitomo S, Shoda H, Sakaguchi $S$ et al (2009) CD4+CD25-LAG3+ regulatory T cells controlled by the transcription factor Egr-2. Proc Natl Acad Sci U S A 106(33):13974-13979

46. Bushell A, Wood K (2007) GITR ligation blocks allograft protection by induced $\mathrm{CD} 25+\mathrm{CD} 4+$ regulatory $\mathrm{T}$ cells without enhancing effector T-cell function. Am J Transpl 7(4):759-768

47. Anvari S, Grimbergen A, Davis CM, Makedonas G (2017) Protein transport inhibitors downregulate the expression of LAG-3 on regulatory T cells. J Immunol Methods 447:47-51

48. Bilate AM, Lafaille JJ (2012) Induced CD4+Foxp3+ regulatory $\mathrm{T}$ cells in immune tolerance. Annu Rev Immunol 30:733-758

49. Miyara M, Yoshioka Y, Kitoh A, Shima T, Wing K, Niwa A et al (2009) Functional delineation and differentiation dynamics of human $\mathrm{CD} 4+\mathrm{T}$ cells expressing the FoxP3 transcription factor. Immunity 30(6):899-911

50. Okamura T, Yamamoto K, Fujio K (2018) Early growth response gene 2-expressing CD4(+)LAG3(+) regulatory T cells: the therapeutic potential for treating autoimmune diseases. Front Immunol 9:340

51. Gregori S, Roncarolo MG (2018) Engineered T regulatory type 1 cells for clinical application. Front Immunol 9:233

52. Kanamori M, Nakatsukasa H, Okada M, Lu Q, Yoshimura A (2016) Induced regulatory T cells: their development, stability, and applications. Trends Immunol 37(11):803-811

53. Kleinewietfeld M, Hafler DA (2014) Regulatory T cells in autoimmune neuroinflammation. Immunol Rev 259(1):231-244

54. Mayo L, Cunha AP, Madi A, Beynon V, Yang Z, Alvarez JI et al (2016) IL-10-dependent $\operatorname{Tr} 1$ cells attenuate astrocyte activation and ameliorate chronic central nervous system inflammation. Brain 139(Pt 7):1939-1957

55. Fujio K, Yamamoto K, Okamura T (2017) Overview of LAG3 -expressing, IL-10-producing regulatory T cells. Curr Top Microbiol Immunol 410:29-45

56. Roncarolo MG, Gregori S, Bacchetta R, Battaglia M (2014) Tr1 cells and the counter-regulation of immunity: natural mechanisms and therapeutic applications. Curr Top Microbiol Immunol 380:39-68

57. Zhang H, Kong H, Zeng X, Guo L, Sun X, He S (2014) Subsets of regulatory $\mathrm{T}$ cells and their roles in allergy. J Transl Med $12: 125$

58. Park JH, Eberl G (2018) Type 3 regulatory T cells at the interface of symbiosis. J Microbiol 56(3):163-171

59. Yang BH, Hagemann S, Mamareli P, Lauer U, Hoffmann U, Beckstette $\mathrm{M}$ et al (2016) Foxp3(+) T cells expressing RORgammat represent a stable regulatory T-cell effector lineage with enhanced suppressive capacity during intestinal inflammation. Mucosal Immunol 9(2):444-457

60. Kitz A, Singer E, Hafler D (2018) Regulatory T cells: from discovery to autoimmunity. Cold Spring Harb Perspect Med. https ://doi.org/10.1101/cshperspect.a029041

61. Collison LW, Workman CJ, Kuo TT, Boyd K, Wang Y, Vignali KM et al (2007) The inhibitory cytokine IL-35 contributes to regulatory T-cell function. Nature 450(7169):566-569

62. Choi J, Leung PS, Bowlus C, Gershwin ME (2015) IL-35 and autoimmunity: a comprehensive perspective. Clin Rev Allergy Immunol 49(3):327-332

63. Sakkas LI, Mavropoulos A, Perricone C, Bogdanos DP (2018) IL-35: a new immunomodulator in autoimmune rheumatic diseases. Immunol Res 66(3):305-312

64. Wei X, Zhang J, Gu Q, Huang M, Zhang W, Guo J et al (2017) Reciprocal expression of IL-35 and IL-10 defines two distinct effector treg subsets that are required for maintenance of immune tolerance. Cell Rep 21(7):1853-1869

65. Choi JK, Dambuza IM, He C, Yu CR, Uche AN, Mattapallil MJ et al (2017) IL-12p35 inhibits neuroinflammation and 
ameliorates autoimmune encephalomyelitis. Front Immunol 8:1258

66. Procaccini C, De Rosa V, Pucino V, Formisano L, Matarese G (2015) Animal models of multiple sclerosis. Eur J Pharmacol 759:182-191

67. Rangachari M, Kuchroo VK (2013) Using EAE to better understand principles of immune function and autoimmune pathology. J Autoimmun 45:31-39

68. Ben-Nun A, Kaushansky N, Kawakami N, Krishnamoorthy G, Berer K, Liblau R et al (2014) From classic to spontaneous and humanized models of multiple sclerosis: impact on understanding pathogenesis and drug development. J Autoimmun 54:33-50

69. Reddy J, Illes Z, Zhang X, Encinas J, Pyrdol J, Nicholson L et al (2004) Myelin proteolipid protein-specific CD4+CD25+ regulatory cells mediate genetic resistance to experimental autoimmune encephalomyelitis. Proc Natl Acad Sci U S A 101(43):15434-15439

70. Kohm AP, Carpentier PA, Anger HA, Miller SD (2002) Cutting edge: $\mathrm{CD} 4+\mathrm{CD} 25+$ regulatory $\mathrm{T}$ cells suppress antigenspecific autoreactive immune responses and central nervous system inflammation during active experimental autoimmune encephalomyelitis. J Immunol 169(9):4712-4716

71. Korn T, Anderson AC, Bettelli E, Oukka M (2007) The dynamics of effector T cells and Foxp3+ regulatory T cells in the promotion and regulation of autoimmune encephalomyelitis. J Neuroimmunol 191(1-2):51-60

72. Montero E, Nussbaum G, Kaye JF, Perez R, Lage A, Ben-Nun A et al (2004) Regulation of experimental autoimmune encephalomyelitis by CD4+, CD25+ and CD8+T cells: analysis using depleting antibodies. J Autoimmun 23(1):1-7

73. Zhang R, Tian A, Wang J, Shen X, Qi G, Tang Y (2015) miR26a modulates Th17/T reg balance in the EAE model of multiple sclerosis by targeting IL6. Neuromolecular Med 17(1):24-34

74. Danikowski KM, Jayaraman S, Prabhakar BS (2017) Regulatory $\mathrm{T}$ cells in multiple sclerosis and myasthenia gravis. J Neuroinflammation 14(1):117

75. Yan Y, Zhang GX, Gran B, Fallarino F, Yu S, Li H et al (2010) IDO upregulates regulatory $\mathrm{T}$ cells via tryptophan catabolite and suppresses encephalitogenic $\mathrm{T}$ cell responses in experimental autoimmune encephalomyelitis. J Immunol 185(10):5953-5961

76. Abdolahi M, Yavari P, Honarvar NM, Bitarafan S, Mahmoudi M, Saboor-Yaraghi AA (2015) Molecular mechanisms of the action of vitamin A in Th17/Treg axis in multiple sclerosis. J Mol Neurosci 57(4):605-613

77. Kim YC, Zhang AH, Yoon J, Culp WE, Lees JR, Wucherpfennig KW et al (2018) Engineered MBP-specific human Tregs ameliorate MOG-induced EAE through IL-2-triggered inhibition of effector T cells. J Autoimmun 92:77-86

78. LaMothe RA, Kolte PN, Vo T, Ferrari JD, Gelsinger TC, Wong $\mathrm{J}$ et al (2018) Tolerogenic Nanoparticles induce antigen-specific regulatory $\mathrm{T}$ cells and provide therapeutic efficacy and transferrable tolerance against experimental autoimmune encephalomyelitis. Front Immunol 9:281

79. Feger U, Luther C, Poeschel S, Melms A, Tolosa E, Wiendl H (2007) Increased frequency of CD4+CD25+ regulatory T cells in the cerebrospinal fluid but not in the blood of multiple sclerosis patients. Clin Exp Immunol 147(3):412-418

80. Anderton SM (2010) Treg and T-effector cells in autoimmune CNS inflammation: a delicate balance, easily disturbed. Eur J Immunol 40(12):3321-3324

81. Venken K, Hellings N, Liblau R, Stinissen P (2010) Disturbed regulatory $\mathrm{T}$ cell homeostasis in multiple sclerosis. Trends Mol Med 16(2):58-68

82. Viglietta V, Baecher-Allan C, Weiner HL, Hafler DA (2004) Loss of functional suppression by CD4+CD25+ regulatory T cells in patients with multiple sclerosis. J Exp Med 199(7):971-979
83. Astier AL, Hafler DA (2007) Abnormal Tr1 differentiation in multiple sclerosis. J Neuroimmunol 191(1-2):70-78

84. Ochoa-Reparaz J, Kasper LH (2017) The influence of gut-derived CD39 regulatory T cells in CNS demyelinating disease. Transl Res 179:126-138

85. Venken K, Hellings N, Thewissen M, Somers V, Hensen K, Rummens JL et al (2008) Compromised CD4+CD25(high) regulatory $\mathrm{T}$-cell function in patients with relapsing-remitting multiple sclerosis is correlated with a reduced frequency of FOXP3-positive cells and reduced FOXP3 expression at the single-cell level. Immunology 123(1):79-89

86. Frisullo G, Nociti V, Iorio R, Patanella AK, Caggiula M, Marti A et al (2009) Regulatory T cells fail to suppress CD4T+-bet+T cells in relapsing multiple sclerosis patients. Immunology 127(3):418-428

87. Haas J, Fritzsching B, Trubswetter P, Korporal M, Milkova L, Fritz B et al (2007) Prevalence of newly generated naive regulatory $\mathrm{T}$ cells (Treg) is critical for Treg suppressive function and determines Treg dysfunction in multiple sclerosis. J Immunol 179(2):1322-1330

88. Nicoletti F, Patti F, Cocuzza C, Zaccone P, Nicoletti A, Di Marco $R$ et al (1996) Elevated serum levels of interleukin-12 in chronic progressive multiple sclerosis. J Neuroimmunol 70(1):87-90

89. Dominguez-Villar M, Baecher-Allan CM, Hafler DA (2011) Identification of T helper type 1-like, Foxp3+ regulatory T cells in human autoimmune disease. Nat Med 17(6):673-675

90. Kitz A, Dominguez-Villar M (2017) Molecular mechanisms underlying Th1-like Treg generation and function. Cell Mol Life Sci 74(22):4059-4075

91. McClymont SA, Putnam AL, Lee MR, Esensten JH, Liu W, Hulme MA et al (2011) Plasticity of human regulatory T cells in healthy subjects and patients with type 1 diabetes. J Immunol 186(7):3918-3926

92. De Matteis S, Molinari C, Abbati G, Rossi T, Napolitano R, Ghetti M et al (2018) Immunosuppressive Treg cells acquire the phenotype of effector-T cells in chronic lymphocytic leukemia patients. J Transl Med 16(1):172

93. Beriou G, Costantino CM, Ashley CW, Yang L, Kuchroo VK, Baecher-Allan C et al (2009) IL-17-producing human peripheral regulatory $\mathrm{T}$ cells retain suppressive function. Blood 113(18):4240-4249

94. Kleinewietfeld M, Hafler DA (2013) The plasticity of human Treg and Th17 cells and its role in autoimmunity. Semin Immunol 25(4):305-312

95. Kemper C, Chan AC, Green JM, Brett KA, Murphy KM, Atkinson JP (2003) Activation of human CD4+ cells with CD3 and CD46 induces a T-regulatory cell 1 phenotype. Nature 421(6921):388-392

96. Mauri C, Menon M (2017) Human regulatory B cells in health and disease: therapeutic potential. J Clin Investig 127(3):772-779

97. Kalampokis I, Yoshizaki A, Tedder TF (2013) IL-10-producing regulatory B cells (B10 cells) in autoimmune disease. Arthritis Res Ther 15(Suppl 1):S1

98. Bjarnadottir K, Benkhoucha M, Merkler D, Weber MS, Payne NL, Bernard CC et al (2016) B cell-derived transforming growth factor-beta1 expression limits the induction phase of autoimmune neuroinflammation. Sci Rep 6:34594

99. Sarvaria A, Madrigal JA, Saudemont A (2017) B cell regulation in cancer and anti-tumor immunity. Cell Mol Immunol 14(8):662-674

100. Fillatreau S (2016) Regulatory roles of B cells in infectious diseases. Clin Exp Rheumatol 34(4 Suppl 98):1-5

101. Wortel CM, Heidt S (2017) Regulatory B cells: phenotype, function and role in transplantation. Transpl Immunol 41:1-9

102. Gallego-Valle J, Perez-Fernandez VA, Correa-Rocha R, Pion M (2018) Generation of human breg-like phenotype with regulatory 
function in vitro with bacteria-derived oligodeoxynucleotides. Int J Mol Sci 19(6):1737

103. Vadasz Z, Toubi E (2017) FoxP3 expression in macrophages, cancer, and B cells-is it real? Clin Rev Allergy Immunol 52(3):364-372

104. Flores-Borja F, Bosma A, Ng D, Reddy V, Ehrenstein, Isenberg DA et al (2013) CD19+CD24hiCD38hi B cells maintain regulatory T cells while limiting TH1 and TH17 differentiation. Sci Transl Med 5(173):173ra23

105. Iwata Y, Matsushita T, Horikawa M, Dilillo DJ, Yanaba K, Venturi GM et al (2011) Characterization of a rare IL-10-competent $\mathrm{B}$-cell subset in humans that parallels mouse regulatory B10 cells. Blood 117(2):530-541

106. Rosser EC, Mauri C (2015) Regulatory B cells: origin, phenotype, and function. Immunity 42(4):607-612

107. Dominguez-Pantoja M, Lopez-Herrera G, Romero-Ramirez $\mathrm{H}$, Santos-Argumedo L, Chavez-Rueda AK, Hernandez-Cueto A et al (2018) CD38 protein deficiency induces autoimmune characteristics and its activation enhances IL-10 production by regulatory B cells. Scand J Immunol 87(6):e12664

108. Qin J, Zhou J, Fan C, Zhao N, Liu Y, Wang S et al (2017) Increased circulating Th17 but decreased CD4(+)Foxp3(+) Treg and CD19(+)CD1d(hi)CD5(+) Breg subsets in new-onset graves' disease. Biomed Res Int 2017:8431838

109. Han J, Sun L, Wang Z, Fan X, Wang L, Song YY et al (2017) Circulating regulatory $B$ cell subsets in patients with neuromyelitis optica spectrum disorders. Neurol Sci 38(7):1205-1212

110. Zhang Y, Li J, Zhou N, Zhang Y, Wu M, Xu J et al (2017) The unknown aspect of BAFF: inducing IL-35 production by a CD5(+)CD1d(hi)FcgammaRIIb(hi) regulatory B-Cell subset in Lupus. J Invest Dermatol 137(12):2532-2543

111. Natarajan P, Singh A, McNamara JT, Secor ER Jr, Guernsey LA, Thrall RS et al (2012) Regulatory B cells from hilar lymph nodes of tolerant mice in a murine model of allergic airway disease are CD5+, express TGF-beta, and co-localize with CD4+Foxp3+T cells. Mucosal Immunol 5(6):691-701

112. Kessel A, Haj T, Peri R, Snir A, Melamed D, Sabo E et al (2012) Human CD19(+)CD25(high) B regulatory cells suppress proliferation of CD4(+) T cells and enhance Foxp3 and CTLA-4 expression in T-regulatory cells. Autoimmun Rev 11(9):670-677

113. Lino AC, Dang VD, Lampropoulou V, Welle A, Joedicke J, Pohar $\mathrm{J}$ et al (2018) LAG-3 inhibitory receptor expression identifies immunosuppressive natural regulatory plasma cells. Immunity 49(1):120-133

114. van de Veen W (2017) The role of regulatory B cells in allergen immunotherapy. Curr Opin Allergy Clin Immunol 17(6):447-452

115. van de Veen W, Stanic B, Wirz OF, Jansen K, Globinska A, Akdis M (2016) Role of regulatory B cells in immune tolerance to allergens and beyond. J Allergy Clin Immunol 138(3):654-665

116. Matsumoto M, Baba A, Yokota T, Nishikawa H, Ohkawa Y, Kayama $\mathrm{H}$ et al (2014) Interleukin-10-producing plasmablasts exert regulatory function in autoimmune inflammation. Immunity 41(6): 1040-1051

117. Carter NA, Vasconcellos R, Rosser EC, Tulone C, Munoz-Suano A, Kamanaka M et al (2011) Mice lacking endogenous IL10-producing regulatory $\mathrm{B}$ cells develop exacerbated disease and present with an increased frequency of Th1/Th17 but a decrease in regulatory T cells. J Immunol 186(10):5569-5579

118. Liu Y, Cheng LS, Wu SD, Wang SQ, Li L, She WM et al (2016) IL-10-producing regulatory B-cells suppressed effector T-cells but enhanced regulatory T-cells in chronic HBV infection. Clin Sci (Lond) 130(11):907-919

119. Aravena O, Ferrier A, Menon M, Mauri C, Aguillon JC, Soto L et al (2017) TIM-1 defines a human regulatory B cell population that is altered in frequency and function in systemic sclerosis patients. Arthritis Res Ther 19(1):8

120. Tarique M, Naz H, Kurra SV, Saini C, Naqvi RA, Rai R et al (2018) Interleukin-10 producing regulatory B cells transformed CD4(+)CD25(-) into tregs and enhanced regulatory T cells function in human leprosy. Front Immunol 9:1636

121. Moore C, Sauma D, Reyes PA, Morales J, Rosemblatt M, Bono MR et al (2010) Dendritic cells and B cells cooperate in the generation of CD4(+)CD25(+)FOXP3(+) allogeneic T cells. Transpl Proc 42(1):371-375

122. Tian J, Zekzer D, Hanssen L, Lu Y, Olcott A, Kaufman DL (2001) Lipopolysaccharide-activated B cells down-regulate Th1 immunity and prevent autoimmune diabetes in nonobese diabetic mice. J Immunol 167(2):1081-1089

123. Parekh VV, Prasad DV, Banerjee PP, Joshi BN, Kumar A, Mishra GC (2003) B cells activated by lipopolysaccharide, but not by anti-Ig and anti-CD40 antibody, induce anergy in CD8+T cells: role of TGF-beta 1. J Immunol 170(12):5897-5911

124. Fillatreau S, Sweenie CH, McGeachy MJ, Gray D, Anderton SM (2002) B cells regulate autoimmunity by provision of IL-10. Nat Immunol 3(10):944-950

125. Matsushita T, Yanaba K, Bouaziz JD, Fujimoto M, Tedder TF (2008) Regulatory B cells inhibit EAE initiation in mice while other B cells promote disease progression. J Clin Investig 118(10):3420-3430

126. Tedder TF (2015) B10 cells: a functionally defined regulatory B cell subset. J Immunol 194(4):1395-1401

127. Egwuagu CE, Yu CR (2015) Interleukin 35-producing B Cells (i35-Breg): a new mediator of regulatory B-cell functions in CNS autoimmune diseases. Crit Rev Immunol 35(1):49-57

128. Khan AR, Hams E, Floudas A, Sparwasser T, Weaver CT, Fallon PG (2015) PD-L1hi B cells are critical regulators of humoral immunity. Nat Commun 6:5997

129. Ray A, Wang L, Dittel BN (2015) IL-10-independent regulatory B-cell subsets and mechanisms of action. Int Immunol 27(10):531-536

130. Murphy KM, Nelson CA, Sedy JR (2006) Balancing co-stimulation and inhibition with BTLA and HVEM. Nat Rev Immunol 6(9):671-681

131. M'Hidi H, Thibult ML, Chetaille B, Rey F, Bouadallah R, Nicollas $\mathrm{R}$ et al (2009) High expression of the inhibitory receptor BTLA in T-follicular helper cells and in B-cell small lymphocytic lymphoma/chronic lymphocytic leukemia. Am J Clin Pathol 132(4):589-596

132. Pennati A, Ng S, Wu Y, Murphy JR, Deng J, Rangaraju S et al (2016) Regulatory B cells induce formation of IL-10-expressing $\mathrm{T}$ cells in mice with autoimmune neuroinflammation. J Neurosci 36(50):12598-12610

133. Huarte E, Jun S, Rynda-Apple A, Golden S, Jackiw L, Hoffman $C$ et al (2016) Regulatory $\mathrm{T}$ cell dysfunction Acquiesces to BTLA+regulatory B cells subsequent to oral intervention in experimental autoimmune encephalomyelitis. J Immunol 196(12):5036-5046

134. Ray A, Mann MK, Basu S, Dittel BN (2011) A case for regulatory B cells in controlling the severity of autoimmune-mediated inflammation in experimental autoimmune encephalomyelitis and multiple sclerosis. J Neuroimmunol 230(1-2):1-9

135. Han J, Sun L, Fan X, Wang Z, Cheng Y, Zhu J et al (2016) Role of regulatory b cells in neuroimmunologic disorders. J Neurosci Res 94(8):693-701

136. Mavropoulos A, Simopoulou T, Varna A, Liaskos C, Katsiari CG, Bogdanos DP et al (2016) Breg cells are numerically decreased and functionally impaired in patients with systemic sclerosis. Arthritis Rheumatol 68(2):494-504

137. Blair PA, Norena LY, Flores-Borja F, Rawlings DJ, Isenberg DA, Ehrenstein MR et al (2010) CD19(+)CD24(hi)CD38(hi) B 
cells exhibit regulatory capacity in healthy individuals but are functionally impaired in systemic lupus erythematosus patients. Immunity 32(1):129-140

138. Li W, Tian X, Lu X, Peng Q, Shu X, Yang H et al (2016) Significant decrease in peripheral regulatory B cells is an immunopathogenic feature of dermatomyositis. Sci Rep 6:27479

139. Mavropoulos A, Varna A, Zafiriou E, Liaskos C, Alexiou I, Roussaki-Schulze A et al (2017) IL-10 producing Bregs are impaired in psoriatic arthritis and psoriasis and inversely correlate with IL-17- and IFNgamma-producing T cells. Clin Immunol 184:33-41

140. Daien CI, Gailhac S, Mura T, Audo R, Combe B, Hahne M et al (2014) Regulatory B10 cells are decreased in patients with rheumatoid arthritis and are inversely correlated with disease activity. Arthritis Rheumatol 66(8):2037-2046

141. Knippenberg S, Peelen E, Smolders J, Thewissen M, Menheere $\mathrm{P}$, Cohen Tervaert JW et al (2011) Reduction in IL-10 producing B cells (Breg) in multiple sclerosis is accompanied by a reduced naive/memory Breg ratio during a relapse but not in remission. J Neuroimmunol 239(1-2):80-86

142. Piancone F, Saresella M, Marventano I, La Rosa F, Zoppis M, Agostini S et al (2016) B lymphocytes in multiple sclerosis: bregs and BTLA/CD272 expressing-CD19+lymphocytes modulate disease severity. Sci Rep 6:29699

143. Michel L, Chesneau M, Manceau P, Genty A, Garcia A, Salou $M$ et al (2014) Unaltered regulatory B-cell frequency and function in patients with multiple sclerosis. Clin Immunol 155(2):198-208

144. Habib J, Deng J, Lava N, Tyor W, Galipeau J. Blood B cell and regulatory subset content in multiple sclerosis patients. J Mult Scler (Foster City). 2015;2(2):139. https://doi.org/10.4172/23760389.1000139

145. de Andres C, Tejera-Alhambra M, Alonso B, Valor L, Teijeiro R, Ramos-Medina R et al (2014) New regulatory CD19(+)CD25(+) $\mathrm{B}$-cell subset in clinically isolated syndrome and multiple sclerosis relapse. changes after glucocorticoids. J Neuroimmunol 270(1-2):37-44

146. Kinnunen T, Chamberlain N, Morbach H, Cantaert T, Lynch M, Preston-Hurlburt P et al (2013) Specific peripheral B cell tolerance defects in patients with multiple sclerosis. J Clin Investig 123(6):2737-2741

147. Hirotani M, Niino M, Fukazawa T, Kikuchi S, Yabe I, Hamada $S$ et al (2010) Decreased IL-10 production mediated by Tolllike receptor 9 in B cells in multiple sclerosis. J Neuroimmunol 221(1-2):95-100

148. Okada Y, Ochi H, Fujii C, Hashi Y, Hamatani M, Ashida S et al (2018) Signaling via toll-like receptor 4 and CD40 in B cells plays a regulatory role in the pathogenesis of multiple sclerosis through interleukin-10 production. J Autoimmun 88:103-113

149. Guo S, Chen Q, Liang X, Mu M, He J, Fang Q et al (2018) Reduced peripheral blood regulatory $\mathrm{B}$ cell levels are not associated with the expanded disability status scale score in multiple sclerosis. J Int Med Res 48:3970

150. Giacomini E, Rizzo F, Etna MP, Cruciani M, Mechelli R, Buscarinu MC et al (2018) Thymosin-alpha1 expands deficient IL10-producing regulatory B cell subsets in relapsing-remitting multiple sclerosis patients. Mult Scler 24(2):127-139

151. Moreno Torres I, Garcia-Merino A (2017) Anti-CD20 monoclonal antibodies in multiple sclerosis. Expert Rev Neurother 17(4):359-371

152. Robak T, Robak E (2011) New anti-CD20 monoclonal antibodies for the treatment of B-cell lymphoid malignancies. BioDrugs Clin Immunother, Biopharm Gene Ther 25(1):13-25

153. Quan C, ZhangBao J, Lu J, Zhao C, Cai T, Wang B et al (2015) The immune balance between memory and regulatory B cells in
NMO and the changes of the balance after methylprednisolone or rituximab therapy. J Neuroimmunol 282:45-53

154. Sorensen PS, Lisby S, Grove R, Derosier F, Shackelford S, Havrdova E et al (2014) Safety and efficacy of ofatumumab in relapsing-remitting multiple sclerosis: a phase 2 study. Neurology 82(7):573-581

155. von Budingen HC, Palanichamy A, Lehmann-Horn K, Michel BA, Zamvil SS (2015) Update on the autoimmune pathology of multiple sclerosis: B-cells as disease-drivers and therapeutic targets. Eur Neurol 73(3-4):238-246

156. Herbst R, Wang Y, Gallagher S, Mittereder N, Kuta E, Damschroder $\mathrm{M}$ et al (2010) B-cell depletion in vitro and in vivo with an afucosylated anti-CD19 antibody. J Pharmacol Exp Ther 335(1):213-222

157. Tedder TF (2009) CD19: a promising B cell target for rheumatoid arthritis. Nat Rev Rheumatol 5(10):572-577

158. Chen D, Blazek M, Ireland S, Ortega S, Kong X, Meeuwissen A et al (2014) Single dose of glycoengineered anti-CD19 antibody (MEDI551) disrupts experimental autoimmune encephalomyelitis by inhibiting pathogenic adaptive immune responses in the bone marrow and spinal cord while preserving peripheral regulatory mechanisms. J Immunol 193(10):4823-4832

159. Chen D, Ireland SJ, Davis LS, Kong X, Stowe AM, Wang Y et al (2016) Autoreactive CD19+CD20- plasma cells contribute to disease severity of experimental autoimmune encephalomyelitis. J Immunol 196(4):1541-1549

160. Rotondi M, Molteni M, Leporati P, Capelli V, Marino M, Chiovato L (2017) Autoimmune thyroid diseases in patients treated with alemtuzumab for multiple sclerosis: an example of selective anti-TSH-receptor immune response. Front Endocrinol (Lausanne) 8:254

161. Simon M, Ipek R, Homola GA, Rovituso DM, Schampel A, Kleinschnitz C et al (2018) Anti-CD52 antibody treatment depletes B cell aggregates in the central nervous system in a mouse model of multiple sclerosis. J Neuroinflammation 15(1):225

162. Liu J, Wang H, Li Y, Shi P, Gong J, Gu L, et al. (2018) Antimouse CD52 treatment ameliorates colitis through suppressing Th1/17 mediated inflammation and promoting Tregs differentiation in IL-10 deficient mice. Biol Pharm Bull

163. Zhang X, Tao Y, Chopra M, Ahn M, Marcus KL, Choudhary N et al (2013) Differential reconstitution of T cell subsets following immunodepleting treatment with alemtuzumab (anti-CD52 monoclonal antibody) in patients with relapsing-remitting multiple sclerosis. J Immunol 191(12):5867-5874

164. De Mercanti S, Rolla S, Cucci A, Bardina V, Cocco E, Vladic A et al (2016) Alemtuzumab long-term immunologic effect: Treg suppressor function increases up to 24 months. Neurol Uroimmunol Neuroinflammation 3(1):194

165. Heidt S, Hester J, Shankar S, Friend PJ, Wood KJ (2012) B cell repopulation after alemtuzumab induction-transient increase in transitional B cells and long-term dominance of naive B cells. Am J Transplant 12(7):1784-1792

166. Baker D, Herrod SS, Alvarez-Gonzalez C, Giovannoni G, Schmierer K (2017) Interpreting lymphocyte reconstitution data from the pivotal phase 3 trials of alemtuzumab. JAMA Neurol 74(8):961-969

167. Dubuisson N, Baker D, Kang AS, Pryce G, Marta M, Visser LH et al (2018) Alemtuzumab depletion failure can occur in multiple sclerosis. Immunology 154(2):253-260

168. Mancuso R, Franciotta D, Rovaris M, Caputo D, Sala A, Hernis A et al (2014) Effects of natalizumab on oligoclonal bands in the cerebrospinal fluid of multiple sclerosis patients: a longitudinal study. Mult Scler. 20(14):1900-1903

169. Warnke C, Stettner M, Lehmensiek V, Dehmel T, Mausberg AK, von Geldern $G$ et al (2015) Natalizumab exerts a suppressive 
effect on surrogates of B cell function in blood and CSF. Mult Scler. 21(8): 1036-1044

170. Stenner MP, Waschbisch A, Buck D, Doerck S, Einsele H, Toyka $\mathrm{KV}$ et al (2008) Effects of natalizumab treatment on Foxp3+T regulatory cells. PLoS ONE 3(10):e3319

171. Putzki N, Baranwal MK, Tettenborn B, Limmroth V, Kreuzfelder E (2010) Effects of natalizumab on circulating B cells, T regulatory cells and natural killer cells. Eur Neurol 63(5):311-317

172. Mitsdoerffer M, Kuchroo V, Korn T (2013) Immunology of neuromyelitis optica: a T cell-B cell collaboration. Ann N Y Acad Sci 1283:57-66

173. Li Y, Wang H, Long Y, Lu Z, Hu X (2011) Increased memory Th17 cells in patients with neuromyelitis optica and multiple sclerosis. J Neuroimmunol 234(1-2):155-160

174. Dos Passos GR, Sato DK, Becker J, Fujihara K (2016) Th17 cells pathways in multiple sclerosis and neuromyelitis optica spectrum disorders: pathophysiological and therapeutic implications. Mediators Inflamm 2016:5314541

175. Huwiler A, Zangemeister-Wittke U (2018) The sphingosine 1-phosphate receptor modulator fingolimod as a therapeutic agent: recent findings and new perspectives. Pharmacol Ther 185:34-49

176. Haas J, Schwarz A, Korporal-Kunke M, Jarius S, Wiendl H, Kieseier BC et al (2015) Fingolimod does not impair T-cell release from the thymus and beneficially affects Treg function in patients with multiple sclerosis. Mult Scler 21(12):1521-1532

177. Muls N, Dang HA, Sindic CJ, van Pesch V (2014) Fingolimod increases CD39-expressing regulatory T cells in multiple sclerosis patients. PLoS ONE 9(11):e113025

178. Breuer J, Herich S, Schneider-Hohendorf T, Chasan AI, Wettschureck N, Gross CC, et al (2017) Dual action by fumaric acid esters synergistically reduces adhesion to human endothelium. Mult Scler: 1352458517735189

179. Chen H, Assmann JC, Krenz A, Rahman M, Grimm M, Karsten $\mathrm{CM}$ et al (2014) Hydroxycarboxylic acid receptor 2 mediates dimethyl fumarate's protective effect in EAE. J Clin Investig 124(5):2188-2192

180. von Glehn F, Dias-Carneiro RPC, Moraes AS, Farias AS, Silva V, Oliveira FTM et al (2018) Dimethyl fumarate downregulates the immune response through the HCA2/GPR109A pathway: implications for the treatment of multiple sclerosis. Mult Scler Relat Disord 23:46-50

181. Fox RJ, Miller DH, Phillips JT, Hutchinson M, Havrdova E, Kita M et al (2012) Placebo-controlled phase 3 study of oral BG-12 or glatiramer in multiple sclerosis. New Engl J Med 367(12):1087-1097

182. Gold R, Kappos L, Arnold DL, Bar-Or A, Giovannoni G, Selmaj $\mathrm{K}$ et al (2012) Placebo-controlled phase 3 study of oral BG-12 for relapsing multiple sclerosis. New Engl J Med 367(12):1098-1107

183. Mills EA, Ogrodnik MA, Plave A, Mao-Draayer Y (2018) Emerging understanding of the mechanism of action for dimethyl fumarate in the treatment of multiple sclerosis. Front Neurol 9:5

184. Lundy SK, Wu Q, Wang Q, Dowling CA, Taitano SH, Mao G et al (2016) Dimethyl fumarate treatment of relapsing-remitting multiple sclerosis influences B-cell subsets. Neurol Neuroimmunol Neuroinflammation 3(2):e211

185. Li R, Rezk A, Ghadiri M, Luessi F, Zipp F, Li H et al (2017) Dimethyl Fumarate Treatment Mediates an Anti-Inflammatory Shift in B Cell Subsets of Patients with Multiple Sclerosis. J Immunol. 198(2):691-698

186. Bar-Or A, Pachner A, Menguy-Vacheron F, Kaplan J, Wiendl H (2014) Teriflunomide and its mechanism of action in multiple sclerosis. Drugs 74(6):659-674

187. Ochoa-Reparaz J, Colpitts SL, Kircher C, Kasper EJ, Telesford $\mathrm{KM}$, Begum-Haque $\mathrm{S}$ et al (2016) Induction of gut regulatory CD39+T cells by teriflunomide protects against EAE. Neurol Neuroimmunol Neuroinflammation 3(6):e291
188. Duda PW, Schmied MC, Cook SL, Krieger JI, Hafler DA (2000) Glatiramer acetate (Copaxone) induces degenerate, Th2-polarized immune responses in patients with multiple sclerosis. J Clin Investig 105(7):967-976

189. Dhib-Jalbut S (2002) Mechanisms of action of interferons and glatiramer acetate in multiple sclerosis. Neurology 58(8 Suppl 4):S3-S9

190. Racke MK, Lovett-Racke AE, Karandikar NJ (2010) The mechanism of action of glatiramer acetate treatment in multiple sclerosis. Neurology 74(Suppl 1):S25-S30

191. Kala M, Rhodes SN, Piao WH, Shi FD, Campagnolo DI, Vollmer TL (2010) B cells from glatiramer acetate-treated mice suppress experimental autoimmune encephalomyelitis. Exp Neurol 221(1):136-145

192. Van Kaer L (2011) Glatiramer acetate for treatment of MS: regulatory B cells join the cast of players. Exp Neurol 227(1):19-23

193. Ireland SJ, Guzman AA, O'Brien DE, Hughes S, Greenberg B, Flores A et al (2014) The effect of glatiramer acetate therapy on functional properties of B cells from patients with relapsing-remitting multiple sclerosis. JAMA Neurology 71(11):1421-1428

194. Jiang H, Milo R, Swoveland P, Johnson KP, Panitch H, Dhib-Jalbut $S$ (1995) Interferon beta-1b reduces interferon gamma-induced antigen-presenting capacity of human glial and B cells. J Neuroimmunol 61(1):17-25

195. Dhib-Jalbut $S$, Marks S (2010) Interferon-beta mechanisms of action in multiple sclerosis. Neurology 74(Suppl 1):S17-S24

196. Schubert RD, Hu Y, Kumar G, Szeto S, Abraham P, Winderl J et al (2015) IFN-beta treatment requires B cells for efficacy in neuroautoimmunity. J Immunol 194(5):2110-2116

197. Comabella M, Rio J, Espejo C, Ruiz de Villa M, Al-Zayat H, Nos C et al (2009) Changes in matrix metalloproteinases and their inhibitors during interferon-beta treatment in multiple sclerosis. Clin Immunol 130(2): 145-150

198. Kasper LH, Reder AT (2014) Immunomodulatory activity of interferon-beta. Ann Clin Transl Neurol 1(8):622-631

199. Chalubinski M, Broncel M (2010) Influence of statins on effector and regulatory immune mechanisms and their potential clinical relevance in treating autoimmune disorders. Med Sci Monit Int Med J Exp Clin Res 16(11):245-251

200. Rodriguez-Perea AL, Montoya CJ, Olek S, Chougnet CA, Velilla PA (2015) Statins increase the frequency of circulating CD4+FOXP3+ regulatory T cells in healthy individuals. J Immunol Res 2015:762506

201. Kim YC, Kim KK, Shevach EM (2010) Simvastatin induces Foxp3+T regulatory cells by modulation of transforming growth factor-beta signal transduction. Immunology 130(4):484-493

202. Peng X, Jin J, Giri S, Montes M, Sujkowski D, Tang Y et al (2006) Immunomodulatory effects of 3-hydroxy-3-methylglutaryl coenzyme-A reductase inhibitors, potential therapy for relapsing remitting multiple sclerosis. J Neuroimmunol 178(1-2):130-139

203. Stuve O, Youssef S, Weber MS, Nessler S, von Budingen HC, Hemmer B et al (2006) Immunomodulatory synergy by combination of atorvastatin and glatiramer acetate in treatment of CNS autoimmunity. J Clin Investig 116(4):1037-1044

204. Palmer MT, Lee YK, Maynard CL, Oliver JR, Bikle DD, Jetten AM et al (2011) Lineage-specific effects of 1,25-dihydroxyvitamin $\mathrm{D}(3)$ on the development of effector CD4 T cells. J Biol Chem 286(2):997-1004

205. Korf H, Wenes M, Stijlemans B, Takiishi T, Robert S, Miani M et al (2012) 1,25-Dihydroxyvitamin D3 curtails the inflammatory and $\mathrm{T}$ cell stimulatory capacity of macrophages through an IL10-dependent mechanism. Immunobiology 217(12):1292-1300

206. Xie Z, Chen J, Zheng C, Wu J, Cheng Y, Zhu S et al (2017) 1,25-dihydroxyvitamin D3 -induced dendritic cells suppress experimental autoimmune encephalomyelitis by increasing proportions of the regulatory lymphocytes and reducing $\mathrm{T}$ helper type 1 and type 17 cells. Immunology 152(3):414-424 
207. Salzer J, Hallmans G, Nystrom M, Stenlund H, Wadell G, Sundstrom P (2012) Vitamin D as a protective factor in multiple sclerosis. Neurology 79(21):2140-2145

208. Soilu-Hanninen M, Laaksonen M, Laitinen I, Eralinna JP, Lilius EM, Mononen I (2008) A longitudinal study of serum 25-hydroxyvitamin D and intact parathyroid hormone levels indicate the importance of vitamin D and calcium homeostasis regulation in multiple sclerosis. J Neurol Neurosurg Psychiatry 79(2):152-157

209. Kimball SM, Ursell MR, O'Connor P, Vieth R (2007) Safety of vitamin D3 in adults with multiple sclerosis. Am J Clin Nutr 86(3):645-651
210. Cantorna MT, Snyder L, Lin YD, Yang L (2015) Vitamin D and 1,25(OH)2D regulation of T cells. Nutrients 7(4):3011-3021

Publisher's Note Springer Nature remains neutral with regard to jurisdictional claims in published maps and institutional affiliations. 